\title{
1. Introduction: trade liberalization in the twenty-first century
}

Razeen Sally

What are the prospects for further economic liberalization in the twentyfirst century? The 'Washington Consensus' attracts greater scepticism now than it did in the 1980s and 1990s, and the momentum of liberalization, globally, has slowed down. An ever greater number of countries seem increasingly reliant on trade negotiations to deliver change, but none seem to want that change to apply to themselves. Besides, historically trade negotiations have delivered little real liberalization; the vast bulk has been driven unilaterally, and the benefits have flowed to the reformers.

How necessary is further liberalization of trade and foreign direct investment? What obstacles lie in its path? What are its political requisites? What are the links with domestic economic reforms? What is the balance between unilateral liberalization and reciprocity (liberalization through trade negotiations and agreements with donors)? How have countries managed these kinds of reforms in the past, and what are the challenges to that process today?

These questions inform the chapters in this excellent collection of country case studies. The seven countries studied - Australia, Brazil, Chile, India, Malaysia, New Zealand and South Africa - present an eclectic mix of histories and circumstances, but are unified by the thrust, if not the finer details, of their trade and broader economic policy choices.

Australia, Chile and New Zealand are the 'strong' reformers in the group. They have more or less eliminated all border barriers to trade and investment, and are well into the much more difficult domestic regulatory reforms that trade opening induces. Malaysia and South Africa have reformed strongly only in parts - both are relatively open at the border (Malaysia much more so than South Africa), with important exceptions, but neither has undertaken any substantive domestic regulatory reforms, or opened sensitive services sectors. Brazil and India are the 'weak' reformers, having each undergone a brief but deep bout of opening within a few years, but very little since. These countries, although transformed by their 
own standards, still have plenty of border and 'behind-the-border' liberalization to do.

Why are these countries' stories important now? The lesser reasons are that a) most of these countries remain understudied, and b) most of their experiences to date have been subject to widely varying interpretations. But the more important reason is that the reform agenda for the twenty-first century remains large and complicated, and the potential benefits from responding to it substantial. By understanding these countries' experiences better, we may draw lessons both for their own remaining reforms, and for those countries further behind in these processes. Many of the countries provide lessons both in what works and what should be avoided. Generally speaking, inward-looking protectionist policies have led to stagnation and ultimately crisis, opening the way for a more sustainable set of policies outward-oriented liberal policies - to take hold.

This introductory chapter reviews the recent history of trade and broader economic liberalization. Much of this has taken place in the developing world (Australia, Ireland and New Zealand are the exceptions), and that is where this chapter is focused. It sets the scene by first assessing the current global climate for external liberalization, which includes debates over the efficacy and usefulness of the Washington Consensus. It then reviews the record of trade and FDI liberalization across the developing world, before probing the political economy of these processes. The framework introduced in that section is replicated in the book's concluding chapter, where lessons are drawn directly from the case studies. It then weighs the effectiveness of the different vehicles for liberalization. What have been the respective roles for unilaterally-driven liberalization as opposed to bilateral, regional and multilateral negotiations, and what will be their respective roles moving forward?

\section{THE GLOBAL CLIMATE FOR EXTERNAL LIBERALIZATION}

To expect, indeed, that the freedom of trade should ever be entirely restored ... is as absurd as to expect that an Oceana or Utopia should ever be established ... Not only the prejudices of the publick, but what is much more unconquerable, the private interests of many individuals, irresistibly oppose it. (Adam Smith, Wealth of Nations)

There is less appetite for further liberalization and associated structural reforms now compared with the heyday of the Washington Consensus in the 1980s and 1990s. Reforms have not been reversed, but their forward momentum has slowed. Governments are more sceptical and defensive 
about further liberalization; and there has been relatively little in the way of 'second-generation' reforms (in domestic trade-related regulations and institutions) to underpin external liberalization and boost competition.

This applies to the West, and to most developing-country regions. In the developed world, pervasive agricultural protectionism continues, with an admixture of new protectionism directed against China. The new 'green' lobby concerned with carbon footprints and 'food miles' coupled with the rise of private standards further threatens the openness of the world trading system. The West has no grand project for liberalization in the early twenty-first century to compare with the Reagan and Thatcher reforms in the 1980s, or the EU's Single Market programme in the late 1980s and early 1990s. Eastern European countries are suffering from 'reform fatigue' after their accession to the EU. This is also the state of play in much of Latin America, Africa, south Asia and southeast Asia. It is true of leading developing countries, notably Brazil, Mexico, South Africa and India. All have their real bursts of trade-and-FDI liberalization behind them. In Russia, liberalization has been put into reverse gear. This has also happened in other resource-rich countries enjoying a revenue windfall, for example Venezuela and Bolivia. Overall, protectionist flare-ups and lack of reform momentum in the West have reinforced liberalization-slowdown in the rest.

China is the conspicuous exception: liberalization proceeded apace before and after WTO accession, in what has been the biggest opening of an economy the world has ever seen. However, domestic political conditions for further liberalization are now more difficult. Vietnam has followed in China's tracks, with internal and external liberalization accelerating in the run up to its WTO accession in 2006.

A variety of factors accounts for liberalization-scepticism today. There is much anxiety about globalisation, despite record growth across the world in the last five years. Macroeconomic crises provided windows of opportunity for fast-and-furious liberalization in the 1980s and 1990s, but that has not happened since the Asian and other financial crises of the late 1990s. Indeed, the latter may have brought about a popular backlash, and certainly induced more caution regarding further liberalization. Also, further liberalization entails tackling border and, increasingly, domestic regulatory barriers in politically sensitive areas such as agriculture and services. Inevitably, this runs up against more powerful interest-group opposition than was the case with previous waves of (mainly industrialgoods) liberalization. Individuals matter too: the new century has not yet brought forth a Cobden, Gladstone, Erhard, Thatcher or Reagan to champion free markets or free trade.

Not least, the climate of ideas has changed, for prevailing weather conditions have become more inclement since the Washington Consensus 
reached its zenith only a decade ago. There is, now as before, an extreme anti-globalization critique, a root-and-branch rejection of capitalism. But this is street theatre on the fringe. Of greater political importance is a more mainstream critique that accepts the reality of the market economy and globalization, but rejects the comprehensive liberalization associated (perhaps unfairly) with the Washington Consensus.

Critics point to tenuous links between liberalization, openness, growth and poverty reduction; wider inequalities within and between countries that result from globalization; the damaging effects of large and sudden trade liberalization in developing countries; the renewed emphasis on aid to poorer developing countries, without which trade liberalization will not work; the need for developed-country liberalization while retaining developingcountry protectionism; and the need for more flexible international rules to allow developing-country governments to pursue selective industrial policies, especially to promote infant industries (Stiglitz, 2002; Rodrik, 1998, 2001; Oxfam, 2002; Chang, 2002; Grunberg, Kaul and Stern, 1999; Sachs, 2005). Lastly, there is the pervasive fear - in the South as much as in the North - of being run over by an unstoppable Chinese export juggernaut.

It is important to confront the liberalization sceptics and industrial interventionists head on; to defend liberalization to date, while accepting that its record is mixed; to make the case for further liberalization; and to identify the political conditions that might make it succeed. Protectionism and industrialpolicy intervention has mostly failed across the developing world: history, not just theory, should be a warning not to go down this route again.

First, in-depth country studies by the OECD, NBER and World Bank, going back to the 1970s and 1980s, suggest strongly that countries with more liberal trade policies have more open economies and grow faster than those with more protectionist policies. These are much more reliable than superficial cross-country regression analyses (Bhagwati and Srinivasan, 1999; Lal and Myint, 1996). That said, even most of the latter point to large gains from trade liberalization (for example Sachs and Warner, 1995; Winters, 2004; Winters et al., 2004).

Putting together calculations done by the World Bank and Angus Maddison, a snapshot of the developing world in the year 2000 reveals the following. There are about 25 'new-globalizing' developing countries (the World Bank's term) with a total population of about 3 billion. Since 1980, this group registered massive increases in their trade-to-GDP ratios and real per-capita incomes, alongside big cuts in levels of tariff protection. In the same period, over 50 'less-globalized' developing countries, with a combined population of about 1.5 billion, saw stagnant trade-to-GDP ratios, a modest increase in real per-capita incomes, alongside relatively modest cuts in average import tariffs. The - overwhelmingly Asian - new 
globalizers have also seen dramatic reductions in poverty and improvements in human-welfare indicators (such as adult literacy, infant mortality, life expectancy and nutritional intake) (World Bank, 2002a: 34, Table 1.1; Maddison, 2003).

Secondly, it is not true that globalization 'excludes' certain developing countries. Rather globalization provides an enabling environment that some countries have taken advantage of and others have not. New globalizers in east Asia, south Asia (first Sri Lanka, and now India), central and eastern Europe, Latin America (notably Chile) and elsewhere have reaped the benefits through more market-oriented policies and institutions. They are narrowing the wealth gap with the West. This is why global poverty has been massively reduced (especially as a percentage of world population, and even in absolute numbers, despite a growing world population). Political disorder, macroeconomic instability, insecure property rights, rampant government intervention and high external protection have kept other countries 'non-globalized' and thereby retarded growth and development. Most of these countries are cursed with dysfunctional or failed states run by venal, thuggish, even murderous elites. None of this is 'caused' by globalization (Henderson, 2004: 52-58; Wolf, 2004: ch. 9).

Thirdly, NGOs and developing-country governments have been clamouring for one-sided liberalization in the Doha Round. Their interpretation of 'development' in the Doha Development Agenda is that it behoves developed countries to liberalize in areas that are protected against labourintensive developing-country exports. But developing countries should not reciprocate with their own liberalization (Oxfam, 2002). What Oxfam and others fail to say is that developing countries' own protectionist policies harm them even more than developed-country barriers. The World Bank estimates that 80 per cent of the developing-country gain from worldwide agricultural liberalization would come from developing countries' liberalization of their highly protected agricultural markets. It is unskilled rural labour - the poorest of the poor - who would gain most, as such liberalization would reduce the anti-agricultural bias in domestic economies (Ingco and Nash, 2004).

Fourthly, the historical record is not kind to 'hard' industrial policies of the infant-industry variety. Infant-industry success in nineteenth-century USA and Germany is contested. In east Asia, its record is mixed at best in Japan, South Korea and Taiwan; non-existent in free-trade Hong Kong and Singapore; and failed in southeast Asia (for example national-car policies in Malaysia and Indonesia). In northeast Asia, there is scant evidence to show that protection of infants actually led to higher social rates of return and higher overall productivity growth (Little, 1999; World Bank, 1993). Southeast Asia's conspicuous success is in FDI-led electronics 
Table 1.1 Bound and applied tariff rates

\begin{tabular}{lccccc}
\hline & \multicolumn{2}{c}{ Bound } & & \multicolumn{2}{c}{ Applied } \\
\cline { 2 - 3 } \cline { 5 - 6 } & $\begin{array}{c}\text { Developed } \\
\text { economies }\end{array}$ & $\begin{array}{c}\text { Developing } \\
\text { economies }\end{array}$ & & $\begin{array}{c}\text { Developed } \\
\text { economies }\end{array}$ & $\begin{array}{c}\text { Developing } \\
\text { economies }\end{array}$ \\
\hline All goods & 17.8 & 43.6 & & 5.5 & 11.8 \\
Agriculture & 24.3 & 60.6 & & 9.5 & 16.3 \\
Manufactures & 16.7 & 32.5 & & 4.8 & 11 \\
\hline
\end{tabular}

Note: Developed and developing economies by World Bank definitions. Developed economies: category 3-4 (2002-2004) and developing economies: category 1-2 (1998-2004).

Source: World Bank Trade Databases: http://siteresources.worldbank.org/INTRES/ Resources/469232-1107449512766/tar2005a.xls

exports - a result of drastically lower tariffs and an open door to inward investment. China, like southeast Asia, has grown fast through FDI-led exports, not infant-industry protection. Arguably, other factors - political and macroeconomic stability, competitive exchange rates, private property rights, openness to the world economy, education and infrastructure were much more important to east-Asian success than 'picking winners'.

Finally, infant-industry protection in Latin America, south Asia and Africa has been a disaster not dissimilar to industrial planning in excommand economies. Protected infants sooner or later ran into severe problems; and governments continued to subsidise and protect perpetual children. Such incestuous government-business links provided a fertile breeding ground for corruption. Besides, most developing-country markets are too small to support infant-industry promotion; and their states are too weak, incompetent and corrupt to efficiently administer the complex instruments required.

\section{Protectionism in the World: Unfinished Business}

Protectionism remains high around the world, even after six decades of liberalization, first in developed countries and then in developing countries. There are pockets of developed-country protection - agricultural subsidies, peak tariffs and tariff escalation in agriculture and manufactures, anti-dumping duties, assorted regulatory barriers such as onerous product standards, and high restrictions on the cross-border movement of workers - that continue to damage developing-country growth prospects.

But developing countries' own protection on almost all these counts is much higher and more damaging. Average applied tariffs in developing countries are more than double those in developed countries, with much 
Table 1.2 Tariff rates in different regions and income groups

\begin{tabular}{lrccc}
\hline Country group or region & Applied & Bound & $\begin{array}{c}\text { Agriculture } \\
\text { (applied) }\end{array}$ & $\begin{array}{c}\text { Manufactures } \\
\text { (applied) }\end{array}$ \\
\hline High income economies & 5.5 & 17.8 & 10.6 & 3.3 \\
Latin America and the & & & & \\
Caribbean & 9.9 & 41.2 & 14.9 & 9 \\
East Asia and Pacific & 10.5 & 29.5 & 16.8 & 10.5 \\
South Asia & 17.8 & 66.5 & 19.1 & 17.2 \\
Europe and Central Asia & 7.8 & 13.2 & 14 & 6.7 \\
Middle East and North Africa & 18 & 34.6 & 22.5 & 16.9 \\
Sub-Saharan Africa & 13.4 & 61.5 & 17.2 & 12.9 \\
\hline
\end{tabular}

Note: The numbers are unweighted averages in percentages from 1998-2004. Regional definitions by the World Bank.

Source: World Bank trade databases: http://siteresources.worldbank.org/INTRES/ Resources/469232-1107449512766/tar2005a.xls

higher bound rates in the WTO (Table 1.1). south Asia, sub-Saharan Africa, the Middle East and north Africa have higher average tariffs than east Asia, Latin America and east Europe (Table 1.2).

Bound and applied tariffs in agriculture are significantly higher than they are in manufactures. Developing countries have become bigger users of anti-dumping actions than developed countries (Figure 1.1). A few developing countries - notably India - have become much more frequent users of anti-dumping actions (Figure 1.2). Developing countries, with the exception of countries in transition and those that have recently acceded to the WTO, have far fewer multilateral commitments than developed countries in services (Figure 1.3).

There has been a general increase in the use of technical, food-safety and other standards that affect trade, as indicated by the number of measures notified under the WTO's Technical Barriers to Trade (TBT) and Sanitary and Phyto-Sanitary (SPS) agreements. This is one - admittedly very rough - indication of regulatory barriers to trade. Developed countries account for over half of TBT and SPS measures notified, but what is also striking is the increasing number of measures notified by developing countries (Figures 1.4 and 1.5).

Thus there is much unfinished business in terms of liberalizing trade, capital flows and the cross-border movement of labour in the developing world. That said, external liberalization is no panacea. In the short run, trade liberalization reduces the anti-import, anti-export bias of trade taxes. That is the prelude to dynamic gains - including those from trade-related 


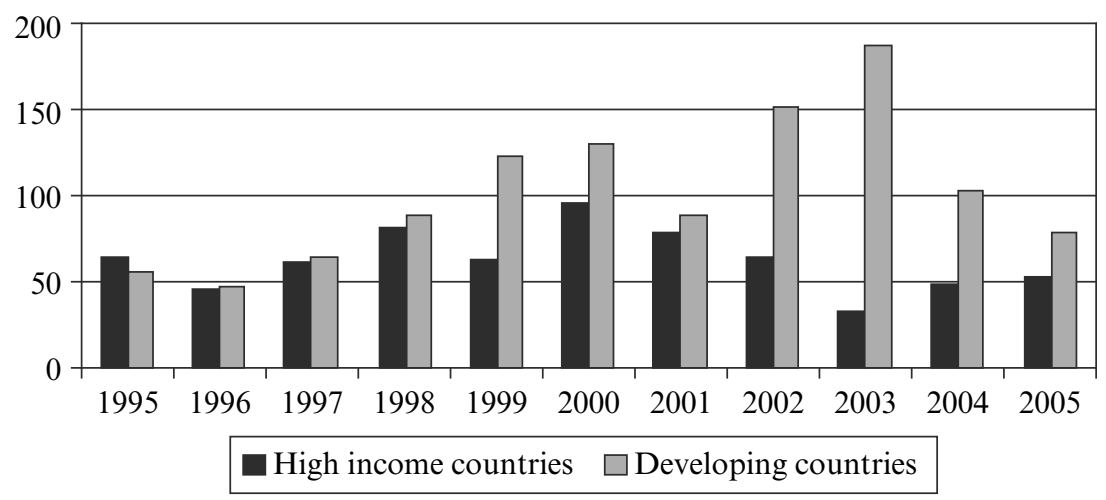

Note: Anti-dumping measures: by reporting Member. Classification of countries by World Bank Definitions.

Source: WTO, http://www.wto.org/english/tratop_e/adp_e/adp_stattab7_e.xls

Figure 1.1 Anti-dumping measures instigated annually, 1995-2005

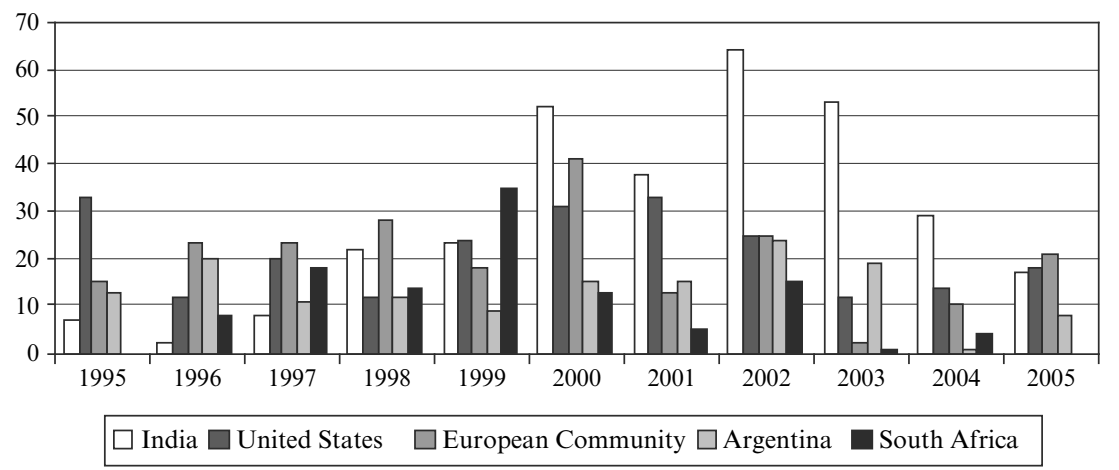

Note: Anti-dumping measures: by reporting Member.

Source: WTO, http://www.wto.org/english/tratop_e/adp_e/adp_stattab7_e.xls

Figure 1.2 Most frequent users of anti-dumping measures, 1995-2005

inward investment - that result in productivity improvements and growth. Capturing these gains, however, depends on additional factors: initial conditions for reform, including a country's factor endowments and historical legacy; complementary domestic market-based reforms; and the state of and improvement in domestic institutions. The connection between opening to the world economy and domestic economic and institutional 
Average number of sub-sectors committed per Member

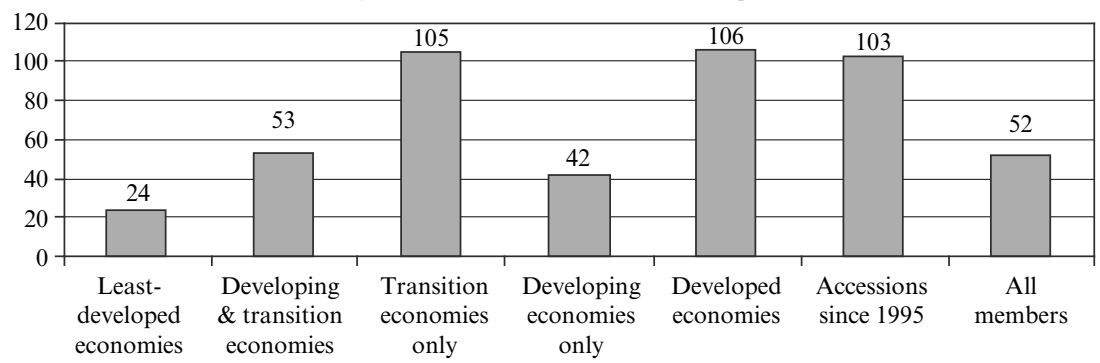

Source: WTO Staff Working Paper ERSD-2005-01, http://www.wto.org/english/res_e/ reser_e/ersd200501_e.doc

Figure 1.3 GATS commitments by country group, 2005

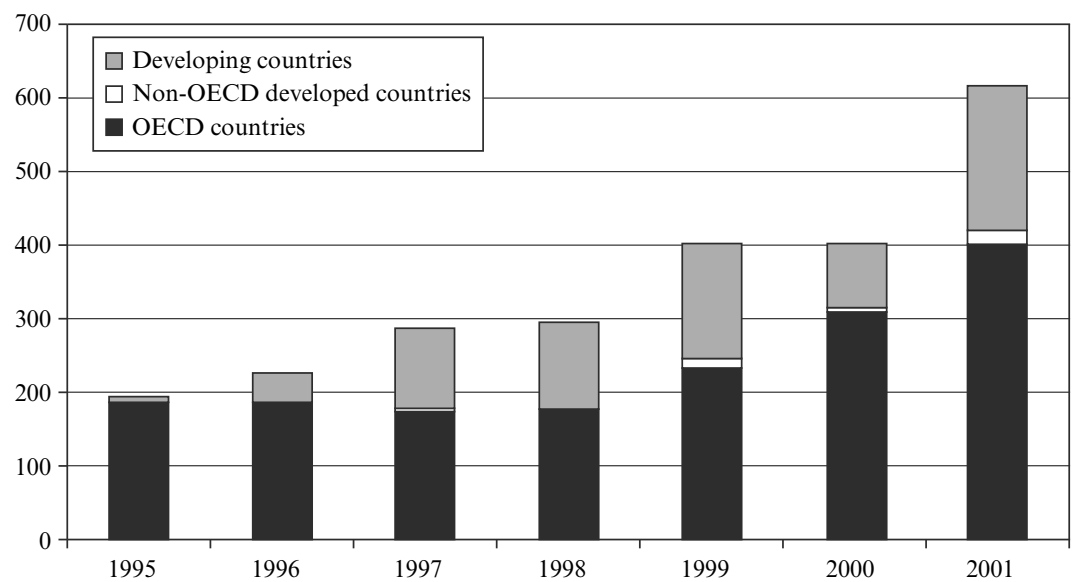

Source: OECD: COM/TD/AGR/WP(2002)21/FINAL, http://www.olis.oecd.org/ olis/2002doc.nsf/43bb6130e5e86e5fc12569fa005d004c/7b8815fac33fe88ec1256bed002e 5cb7/ \$FILE/JT00129244.PDF

Figure 1.4 Notified SPS measures, 1995-2001

reform is particularly important: it is this that explains much of the variation in economic performance in the developing world.

This is not a new insight: David Hume and Adam Smith strongly linked free trade (broadly defined to include cross-border flows of capital and people) to domestic institutions and growth, all on the canvas of the longrun progress of commercial society (Sally, 1998: ch. 3). But this also raises difficult political questions. In essence, successful external opening depends 


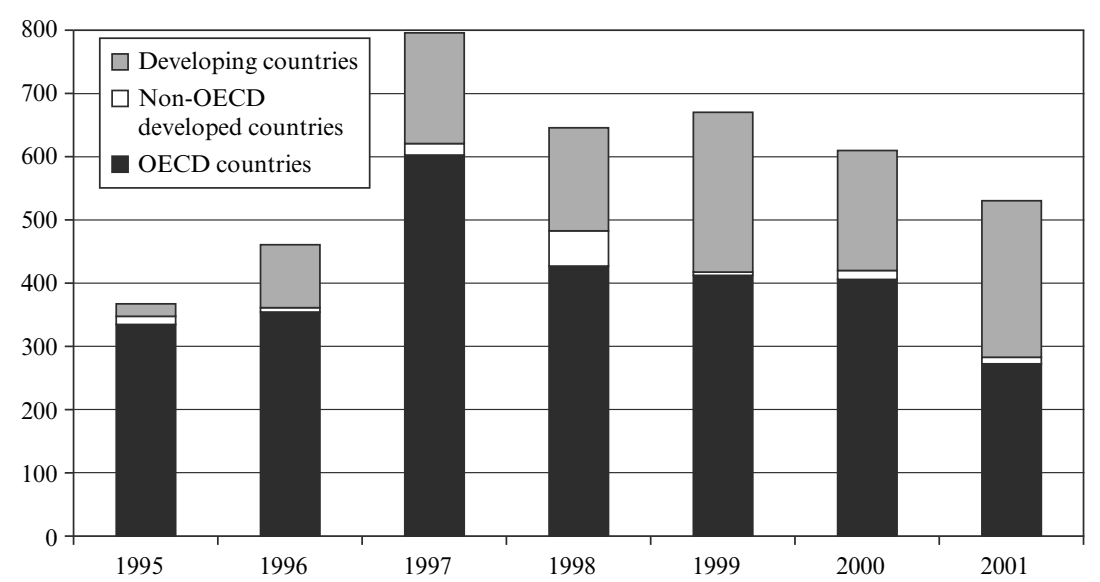

Source: OECD: COM/TD/AGR/WP(2002)70/FINAL, http://www.olis.oecd.org/ olis/2002doc.nsf/43bb6130e5e86e5fc12569fa005d004c/baacb7d0229000f9c1256cdf00418c0f/ \$FILE/JT00140246.PDF

Figure 1.5 Notified TBT measures, 1995-2001

crucially on domestic politics and institutional capacity. Here there are very large and arguably increasing differences within the developing world.

\section{TRADE-POLICY REFORM: THE RECENT EXPERIENCE}

Trade liberalization has several definitions. Trade economists speak of moving to 'neutrality' of government intervention as between tradable and non-tradable sectors of the economy. They also speak of 'getting prices right' by aligning domestic prices with world prices of tradable goods. More broadly conceived, free (or free-ish) trade means the freedom to engage in international transactions, without discrimination (Henderson, 1992: 635). This exists nowhere - not even in Hong Kong, which maintains tight restrictions on immigration, though it is fully open to trade in goods and capital flows, and largely open to trade in services. If nondiscrimination is the relevant criterion, all countries are still far from free trade, indeed more so than was the case in the late nineteenth century.

Nevertheless, there has been a distinct liberalization trend in developing countries in recent decades. ${ }^{1}$ Cross-border trade and capital flows - though not of people - have become freer, and have boomed. There is less discrimination between domestic and international transactions. Domestic prices 
of tradable goods and services are closer to world prices (though less the case in services than in goods). In terms of measures undertaken: import and export quotas, licences, state trading monopolies and other non-tariff barriers have been drastically reduced. Tariffs have been simplified and reduced. So have foreign-exchange controls, with unified exchange rates and much greater currency convertibility, especially on current-account transactions. Foreign direct investment has been liberalized, with fewer restrictions on entry, ownership, establishment and operation in the domestic economy. And services sectors have been opened to international competition through FDI liberalization, privatization and domestic deregulation. Overall, trade and FDI in manufactured goods has been liberalized most; trade and FDI in services was liberalized later, and to a much lesser extent; and trade liberalization in agriculture has lagged behind. Lastly, trade and FDI liberalization has taken place in the context of wideranging macro and microeconomic market-based reforms - roughly the 'stabilization and liberalization' package of the Washington Consensus, as described by John Williamson (Williamson, 1994).

Cumulatively, this has been a veritable policy revolution in developing countries and countries in transition. Before the 1980s, the 80 per cent of the world's population who live outside the West lived overwhelmingly in countries with high levels of external protection, in addition to pervasive government intervention at home. By the mid-1990s, most of these people lived in much more open economies, in terms of both domestic and international commerce (Sachs and Warner, 1995).

Average applied tariffs in developing countries declined from 30 per cent in 1985 to 11 per cent in 2005. Core non-tariff barriers declined correspondingly in all developing-country regions. The bulk of regulatory changes on inward investment have been more favourable to FDI. There has even been a trend in favour of capital-account liberalization: 70 per cent of the developing countries in the IMF maintain capital-account restrictions today, compared with 85 per cent in the early 1990s.

This liberalization trend started in Japan, and then South Korea and Taiwan, in the 1950s, at a time when most developing countries were tightening regimes of import-substitution and other forms of state intervention. The northeast-Asian Tigers promoted exports through selective liberalization, while retaining considerable import protection and restrictions on inward investment. Later they gradually liberalized imports and FDI. Hong Kong returned to tariff-free trade and a fully open door to investment after the war. Singapore followed, though after a brief flirtation with protection (when part of the Malaysian federation). The other southeastAsian Tigers (Malaysia, Thailand, Indonesia and the Philippines) liberalized significantly, on both trade and FDI, from the 1970s. The countries of 
Indochina started gradual and halting market-based reforms in the 1980s. Vietnam accelerated trade-and-investment liberalization in the run up to its WTO accession in late 2006.

China's historic opening dates back to 1978, but major trade-and-investment liberalization took off from the early 1990s. Since then, China has swung from extreme protection to rather liberal trade policies, indeed very liberal by developing-country standards. The protective impact of classic non-tariff barriers (NTBs) has come down to less than 5 per cent; and the simple average tariff has come down from 42 per cent in 1992 to under 10 per cent after WTO accession - below the developing-country average. The crowning point of China's reforms was its WTO accession in 2001. Its WTO commitments are by far the strongest of any developing country in the WTO. This holds for tariff ceilings on goods (including agriculture); non-tariff barriers in goods and services (with big-ticket sectors like financial services, telecoms, retail, transport and a host of professional services thrown open to foreign competition); all manner of strong domestic regulatory disciplines to improve transparency and promote competition; and administrative and judicial-review procedures to ensure that WTO commitments are implemented domestically.

In south Asia, Sri Lanka pioneered external liberalization in the late 1970s. India's retreat from the 'licence raj' - its equivalent of Soviet-style central planning - began half-heartedly in the 1980s; but its decisive opening to the world economy dates back to 1991. The average tariff has come down to about 16 per cent from 125 per cent in 1991. Most border NTBs, internal licensing restrictions and restrictions on manufacturing FDI have gone. This still leaves high protection in agriculture and services. Pakistan followed in the late 1990s.

In Latin America, Chile pioneered radical external liberalization in the 1970s. Other Latin American countries followed in the 1980s (notably Mexico) and the 1990s (notably Brazil, Argentina and Peru). African liberalization was slow in the 1980s and faster in the 1390s. South Africa opened rapidly during and after the end of apartheid. The countries of east-central Europe and the Baltic states experienced a 'big bang' transition from the Plan to the Market after 1989, which included massive liberalization of trade and capital flows. This was less the case, and certainly more erratic, in Russia, other parts of the ex-Soviet Union and southeastern Europe. However, liberalization has recently accelerated in some of these countries, for example Romania, Bulgaria, Georgia and parts of the ex-Yugoslavia.

Finally, trade-and-investment liberalization in the old OECD countries has taken place in small steps since the 1980s - not surprising, since these are largely open economies in which the bulk of liberalization was done in the 1950s and 1960s. The exceptions are Australia and New Zealand. After 
over a century of protection, both opened decisively to the world economy in the 1980s.

\section{THE POLITICAL ECONOMY OF TRADE-POLICY REFORM}

The politics of economic-policy reform is as much about distribution as it is about wealth generation. This is true of international politics; it is even truer of domestic politics. Shifts in trade policy - from protection to openness or vice versa - trigger redistribution of gains and losses between regions (especially between rural and urban areas), sectors of the economy (agriculture, industry, services), classes (owners of capital, educated and skilled workers, semi- and unskilled workers), and even between ethnic groups. Such disruption, especially in the short-term, can be particularly unsettling in developing countries with political instability, corrupt elites, wide disparities in wealth and influence, meagre safety nets, ethnic divides and generally brittle institutions. Hence trade and other forms of liberalization take place in a snakepit of messy and sometimes poisonous politics.

What are the determinants of trade-policy reform, especially in the direction of liberalization? What follows is a simple taxonomy of relevant factors: a) circumstances, especially crises; b) interests; c) ideas; d) institutions; e) factor endowments.

\section{Circumstances and Crises}

Events, dear boy, events. (Harold Macmillan)

When a man knows he is going to be hanged in a fortnight, it concentrates the mind wonderfully. (Dr Johnson)

The practical politician, official or businessman knows that choices are dictated by responses to often unanticipated events. In reality, major episodes of economic-policy reform have mostly taken place in response to political and/or economic crises (Haggard and Williamson, 1993). A macroeconomic crisis, with symptoms such as extreme internal or external indebtedness, hyperinflation, a terms-of-trade shock, or a severe payments imbalance leading to a plummeting currency, provides the classic backdrop. This is when 'normal politics' is suspended, and when a period of 'extraordinary politics' can provide a window of opportunity for thoroughgoing reforms (that would not be possible in 'normal' political circumstances) (Balcerowicz, 1995). Examples are legion: Chile in 1973/4; Mexico in 1986; 
Brazil and Argentina in the early 1990s; South Africa in the mid-1990s; Sri Lanka in 1977; India in 1991; eastern Europe and the ex-Soviet Union in the early 1990s; Australia and New Zealand in 1983/4.

But the crisis explanation cannot be taken too far. First, a crisis can precipitate swings both ways: sometimes towards liberalization; sometimes the other way, as happened during the Depression in the 1930s, and, to a lesser extent, in the 1970s after the first oil price shock. Secondly, different governments act in different ways in response to similar external shocks. Thirdly, a crisis might trigger some reforms, but it is no guarantee of the sustainability of those reforms, nor of further reforms down the line. That is one key difference between east-central Europe and the Baltic states, on the one hand, and Russia and other parts of the ex-Soviet Union, on the other. Lastly, there are counter-examples of gradual, but cumulatively substantial, reforms without a sudden crisis as a triggering mechanism. That is, roughly, the east-Asian record, and that of Australia's.

Why have some countries sustained reforms while others have not? Why have some gone farther than others? What happens to a reform programme post-crisis, when 'normal' political and economic conditions return? These questions demand supplementary explanations.

\section{Interests}

A good cause seldom triumphs without someone's interest behind it. (John Stuart Mill)

Mainstream economists, following Adam Smith, tend to rely on an interest-group explanation of trade politics. Free trade is the optimal policy in most circumstances (they say), but protection more often the result, because organized rent-seeking interests demand protection, and politicians and officials supply it. The benefits of free trade are diffused over the broad majority of consumers, but its costs bear down disproportionately on minority producer interests. The latter, not the former, have the incentive to organize for collective action (Olson, 1971; Krueger, 1974).

In reality 'iron quadrangles' of politicians, bureaucrats, employers and unions imposed a straightjacket of protection in developing countries from the 1930s to the 1970s. Mostly this benefited capital-intensive, unionized, urban manufacturing industries producing for the domestic market, at the expense of agriculture and tradable sectors. India's licence raj was its most notorious incarnation. In many countries, a crisis was used to overcome interest-group opposition and push through liberalizing reforms (as happened in India in 1991).

But what role do interest groups play after an initial burst of external 
liberalization, and in post-crisis conditions when 'normal' politics returns? Here the picture differs across countries and regions. In some parts of the world, protectionist coalitions have halted or slowed down liberalization. This is the case with 'nomenklatura' coalitions in Russia, Ukraine and other parts of the ex-Soviet Union. Elsewhere, radical opening has triggered major economic shifts in favour of sectors exposed to the world economy. Traditional protectionist interests have been weakened, and countervailing coalitions have emerged. The latter comprise exporters, users of imported inputs, multinationals with global production networks, and cities and regions seeking to be magnets for trade and FDI. These interests lobby for the maintenance and extension of open trade and FDI regimes. ${ }^{2}$ This has happened in strong liberalizing countries in east Asia, eastern Europe and Latin America. It happened in Australia and New Zealand from the early 1980s. It is also evident in India after the 1991 reforms.

\section{Ideas}

It is the word in season that does much to decide the result. (John Stuart Mill)

Madmen who hear voices in the air are distilling their frenzy from the academic scribblings of some defunct economist or political philosopher. Indeed the world is ruled by little else. (John Maynard Keynes)

It is difficult to gauge the influence of ideas (or ideology) in policy. ${ }^{3}$ But practical observation teaches us that the prevailing climate of ideas, interacting with interests and events, can entrench or sway this-or-that set of policies. A policy consensus on import substitution, state planning and foreign aid was strongly embedded in developing-country governments and international organizations up to the 1970s. This was buttressed by a post-colonial political ideology of mercantilist state-building, and an interventionist consensus in development economics (Bauer, 2000a; Lal and Myint, 1996). This set of ideas was overturned by what came to be called the Washington Consensus, which reflected sea-changes in political ideology and in development economics. The latter returned to classical and neoclassical foundations, emphasizing market-based pricing, 'outward orientation', the prevalence of 'government failure' over 'market failure', not to mention a dose of aid scepticism.

Washington Consensus ideas took stronger hold in countries where reforms were substantial, especially in ministries of finance, central banks and presidential/prime-ministerial offices. These agencies tend to be the cockpits of policy reform. But now the climate of ideas has changed somewhat. This does not presage a return to full-blown pre-Washington Consensus thinking. The pendulum, however, is swinging towards more 
attention to market failure and government intervention, for example to ease back on further liberalization, expand 'policy space' and promote infant industries, defend 'food security' and increase foreign aid. The question is what effect this is having, and is likely to have, on trade policies.

\section{Institutions}

In the broad sense, institutions are the steel frame of the economy, its 'formal rules and informal constraints', according to Douglass North. The legal framework governing property rights and contracts, production and consumption, comes to mind. 'Formal rules' comprise bankruptcy laws, competition laws, regulations governing financial markets and corporate governance, and much else besides. 'Informal constraints' are (often nonlegal) traditions and norms influencing the intersecting worlds of business, government and the law.

Evidently, 'institutions' are much broader and more difficult to pin down than 'policies'; and the two are of course intimately connected. Historically-conditioned institutions, domestic and external, set the scene for government action, interest-group lobbying and the influence of ideas. They are the arena for policy choices and their implementation. Making generalizations about institutional constraints on policy choice, and how this might explain differences in national and regional economic performance over time, is notoriously difficult. To what extent must 'good' institutions be in place before 'good' policies can take hold and work their magic? Conversely, to what extent are institutions the result, rather than the cause, of policy choices? These are chicken-and-egg questions.

In the narrow sense, institutions are the organizational map of decisionmaking at the junction where politics and public policy meet business and society. On trade policy, this map is much more complicated than it used to be. Trade policy, as we know, is no longer just about a clutch of border instruments, and the preserve of trade ministries. It is increasingly 'trade-related', a matter of non-border regulation reaching deep into the domestic economy and its institutions. That is reflected in more complex multilateral, regional and bilateral trade agreements. This brings in agencies across the range of government and many actors outside government as well. Now the management of trade policy involves: the division of labour between the executive, legislature and judiciary; the role of the lead ministry; the participation of other ministries and regulatory agencies on trade and trade-related policies; the WTO mission in Geneva; inter-agency coordination within government; the involvement of non-governmental actors, such as business and unions, and now including NGOs and think tanks; and the role of donors and international organizations. 
Inasmuch as one can make generalizations about institutions and trade policy in developing countries, here are a couple. First, it is the more advanced developing countries (in terms of per-capita income and human-development indicators) that have liberalized more and plugged themselves better into globalization than other developing countries. They have lower trade and FDI barriers, higher ratios of trade and FDI to GDP, and better-performing tradable sectors of the economy. They also have stronger institutions in the broad sense: better enforcement of property rights and contracts (that is the rule of law), better-functioning judiciaries and public administration, better-regulated financial markets, a stronger competition culture, less corruption and so on (World Bank, 2002a; Michalopoulos, 2001). This is the divide that separates Chile and a few other Latin American countries, eastern Europe, the northeastAsian and southeast-Asian Tigers, and a tiny handful of African countries (Mauritius, Botswana and South Africa), from the rest.

There are, however, two gigantic anomalies: China and India. Both are still low-income countries with weak institutions (going by some of the indicators mentioned above). Institutional improvements have taken place, but these have lagged well behind big policy shifts - not least lower trade and FDI restrictions - and fast-paced global integration. The World Bank's governance and business-climate indicators, for example, point to large institutional and policy differences among developing countries. That is predictable enough. But they also point to relatively weak institutions, as well as the high 'red-tape' costs of doing business, in China and India.

Second, looking at institutions in the narrower organizational sense, strong and sustained trade-policy and wider economic-policy reforms were driven, more often than not, by powerful presidential or prime-ministerial offices, ministries of finance and central banks, insulated from blocking pressures in other parts of government and outside government. This was more pronounced in advanced developing countries than elsewhere. These countries also have stronger capacity, in terms of qualified, experienced manpower and other resources, for formulating and implementing trade policy, whether done unilaterally or through international negotiations and agreements. Again, China and India are exceptional: they are lowincome countries with relatively weak institutions (in the broad sense), but with relatively strong trade-policy capacity.

\section{Factor Endowments}

Explaining the trajectory of policy reforms is not complete without factoring in the relative mix of land (or natural resources), labour (including skills) and capital in an economy (Lal and Myint, 1996). We know from 
recent economic history that the star developing-country performers are east Asian. These countries had different starting positions, but, at a certain stage of development, relative labour abundance allowed them to break into labour-intensive manufactured exports, which became an engine of growth and in turn aided poverty reduction and human-welfare improvement. Of course this was not inevitable: it depended on the right policies and improving institutions. South Asia, with similar factor endowments, remained stuck on a low-growth, high-poverty path because it did not adopt market-based policies.

Latin American and African countries, on the other hand, are largely land- or resource-abundant and labour-scarce. Absent import-substitution policies, they are better able to exploit comparative advantage in land and resources - as Brazil, Argentina, Chile, Australia and New Zealand have done in agriculture since they liberalized, and as all the latter and many other countries are doing in the present China-driven commodities boom. Thus a simple story based on early twenty-first century comparative advantage would point to all-round gains from trade: for technologically-advanced and capital-abundant countries in the West; the labour-abundant countries of east and south Asia; and land and resource-abundant countries elsewhere.

But the political economy of factor endowments reveals a different and more problematic story. Arguably, land- and resource-abundant countries are at a structural disadvantage compared with labour-abundant countries. By plugging into global markets for manufacturing, and now labour-intensive services too, the latter seem to be on sustainable growth paths. Labour-intensive exports attract FDI (and the technology and skills that come with it), feed quickly into poverty-reducing, welfare-improving employment, and, more gradually, into better infrastructure and institutions. This creates and strengthens a constellation of interests to support open trade and FDI policies.

Land- and resource-abundant countries, given their relatively high price of labour, seem to be crowded out of global manufacturing markets by east-Asian (especially Chinese) competition (Wolf, 2004: 146-9). This leaves them dependent on cyclical and volatile commodities markets. FDI in resource-abundant countries tends to be capital-intensive and to generate big rents in not-so-competitive market segments. Often the result is an FDI enclave, without an employment, technology or wealth spillover to the rest of the economy, but with big profits to distribute among a corrupt local business and political elite. Most countries dependent on resources have the interest-group constellation to squander rents from resource booms, but not to spread wealth and improve governance and institutions. A retreat to protectionism, however, would repeat past mistakes and make matters worse. This is the dilemma inherent in the 'China-in-Africa' 
phenomenon. But there are notable exceptions to the 'resource-curse' rule: Chile has successfully exploited comparative advantage in agriculture and resources (mainly copper) through liberal trade policies, while diversifying the economic base and improving institutions. That is also true of Australia and New Zealand.

\section{MULTI-TRACK TRADE POLICY}

Another way of cutting into trade-policy reform is to look at it on several tracks. Some reforms are carried out unilaterally; others reciprocally through (bilateral, regional, multilateral) trade negotiations, or in agreements with donors. Most developing countries now do trade policy on all these tracks concurrently, though the relative balance differs from country to country.

\section{Unilateral liberalization}

I trust the government ... will not resume the policy which they and we have found most inconvenient, namely the haggling with foreign countries about reciprocal concessions, instead of taking that independent course which we believe to be conducive to our own interests ... let us trust that our example, with the proof of practical benefits we derive from it, will at no remote period insure the adoption of the principles on which we have acted. (Sir Robert Peel, announcing the repeal of the Corn Laws, House of Commons, 1846)

Liberalise first, negotiate later. (Mart Laar, former prime minister of Estonia)

Compelling political and economic arguments favour unilateral liberalization, with governments freeing up international trade and flows of capital and labour independently, not in the first instance via international negotiations. As any student of trade economics knows, welfare gains result directly from import liberalization, which replaces comparatively costly domestic production and reallocates resources more efficiently, and spurs capital accumulation, economies of scale as well as longer-run dynamic gains such as the transfer of technology and skills. ${ }^{5}$ Similar and related arguments apply to the liberalization of inward investment and the crossborder movement of people.

Such gains come more quickly through own, unconditional liberalization than through protracted, politicized and bureaucratically cumbersome international negotiations. This Nike strategy ('Just Do It!') can make political sense too. Rather than relying on one-size-fits-all international blueprints, governments have the flexibility to initiate policies and emulate 


\section{Share of total tariff reduction, by type of liberalization, 1983-2003}

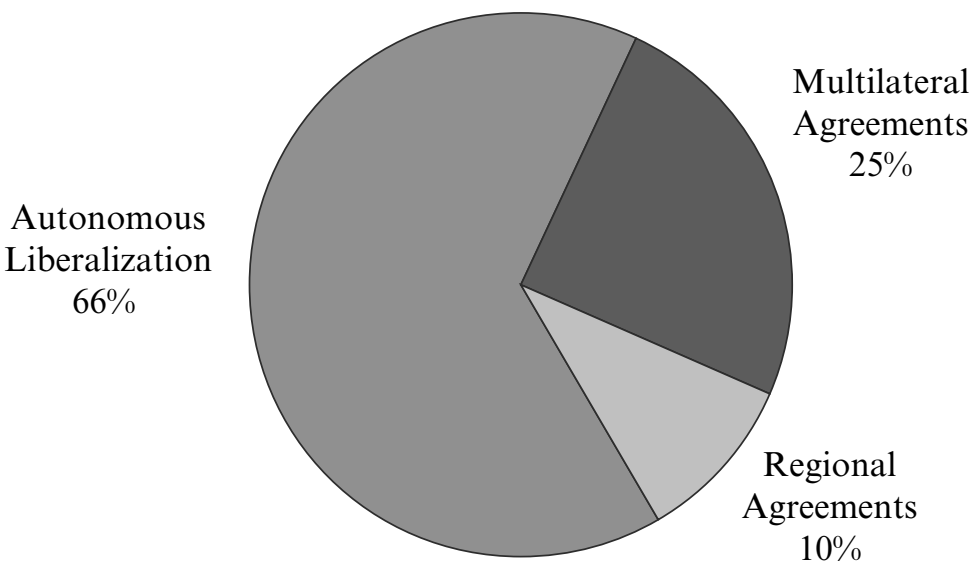

Source: World Bank http://siteresources.worldbank.org/INTGEP2005/Resources/ GEP107053_Ch02.pdf

\section{Figure 1.6 Source of liberalization, 1983-2003}

better practice abroad in experimental, trial-and-error fashion, tailored to specific local conditions. In David Landes's words, it is 'initiated from below and diffused by example'. This was the preferred method of the classical economists from Smith to Marshall, and of the titans of mid-Victorian British politics (Sally, 1998).

In twentieth and twenty-first century conditions of democratic politics and vigorous interest-group lobbying, unilateral liberalization is of course a much more difficult proposition than it was in the nineteenth century. But observers often forget that the recent trade-policy revolution outside the West has come more 'from below' than 'from above'. The World Bank estimates that, between 1983 and 2003, about 65 per cent of developingcountry tariff liberalization (a 21 per cent cut in average weighted tariffs) has come about unilaterally, with 25 per cent coming from the Uruguay Round Agreements and only 10 per cent from preferential trade agreements (PTAs) (Figure 1.6).

True, many governments liberalized reluctantly as part of IMF and World Bank structural adjustment programmes. But the strongest liberalizers have been unilateral liberalizers, going ahead under their own steam without the need for much external pressure. Prominent among them are the east-Asian countries, now led by China, as well as Chile, Mexico, 
the east European countries, Australia, New Zealand and South Africa. Nearly all of India's post-1991 liberalization has been done unilaterally.

Unilateral liberalization of trade and investment has been particularly strong in east Asia. China's massive opening is the most recent example, and was mostly done unilaterally, before WTO accession. Its extremely strong WTO commitments, and its generally constructive participation in the WTO since accession, are more the consequence than the cause of its sweeping unilateral reforms. China is in some ways today what Britain was in the second half of the nineteenth century: the unilateral engine of freer trade. It could well spur a pick-up in trade-and-FDI liberalization elsewhere, especially in Asia. Recently, India has accelerated its liberalization of tariffs and FDI - outside trade negotiations. Would this have happened, or happened as fast, if China had not concentrated minds? Probably not.

That is not to say that China-induced unilateral liberalization is a total solution. It is unlikely to induce further external liberalization in the developed world, and least of all in the USA, EU and Japan. In the developing world, its results will inevitably be patchy and messy. On its own it cannot slay protectionist dragons and solve international commercial conflicts least of all in agricultural trade, where unilateral liberalization has been much more limited than in industrial goods and services. More importantly perhaps, it does not provide binding and enforceable rules for stable and open international commerce. That leaves room for reciprocal negotiations and international agreements, that is for the WTO and PTAs.

\section{Multilateral Liberalization}

The great political virtue of multilateralism, far exceeding in importance its economic virtues, is that it makes it economically possible for most countries, even if small, poor and weak, to live in freedom and with chances of prosperity without having to come to special terms with some Great Power. (Jacob Viner)

In recent years, the impression has often been given of a vehicle with a proliferation of backseat drivers, each seeking a different destination, with no map and no intention of asking the way. (The Sutherland Report)

Given the realities of modern politics - interest-group lobbying for protection, ingrained mercantilist thinking, the perception that liberalization hurts the poor and vulnerable - unilateral liberalization is often difficult to achieve in practice. The rationale of 'multilateralized reciprocity' is that GATT/WTO negotiations help to contain protectionist interests and mobilize exporting interests; and multilateral agreements provide fair, non-discriminatory rules for all. Perhaps the greatest utility of the WTO is that it provides a framework of rules to assist (mainly developing-country) 
governments that have strategically chosen to take their national economies in a market-oriented, globally-integrated direction. The accessions of China and Vietnam are textbook examples of how the WTO should work.

That said, the standard raison dêtre for multilateral rules-based trade liberalization was easier said in the old GATT than done in the WTO. In many ways the WTO is the victim of its own success; of the successful conclusion of the Uruguay Round and the huge transition from the GATT to the WTO. ${ }^{5}$

Multilateral liberalization was successful during the GATT when the latter had a relatively slimline agenda, club-like decision-making dominated by a handful of developed countries (especially the USA and EU), and the glue of Cold War alliance politics. It has proved spectacularly unsuccessful in the WTO. Now, the WTO agenda, especially on nonborder regulation, is technically more complicated, less amenable to the reciprocal exchange of concessions, administratively more burdensome and politically much more controversial; decision-making is a chaotic mess in a general assembly with near-universal membership; and the unifying glue of the Cold War has dissolved. The failure of the Doha round (as of the time of writing) probably shows that future multilateral liberalization will be elusive, and modest at best.

Arguably, the best the WTO can hope for post-Doha is to lock in preexisting unilateral liberalization through binding commitments, and gradually improve the functioning of non-discriminatory multilateral rules. That implies scaling back ambitions and expectations. Market-access and rulemaking negotiations should be more modest and incremental; and maybe trade rounds should become a thing of the past. Perhaps there should be more emphasis on the WTO as an OECD-type forum to share information and ideas, and to improve transparency through mutual policy surveillance, especially for developing countries. More attention should also be given to the technical, everyday task of administering trade rules.

Even achieving these objectives will be a tall order, given the present parlous state of the WTO. There is every prospect that multilateral trade rules will be undermined by major players seeking to evade them, and as a result of proliferating and discriminatory bilateral trade agreements. Weaker multilateral rules will be a much bigger cost for developing countries than the extra multilateral liberalization forgone as a result of Doha round failure.

\section{Bilateral and Regional Liberalization}

We will work with can do, not won't do, countries. (Robert Zoellick)

By July 2005, 330 preferential trade agreements (PTAs) had been notified to the GATT/WTO, 206 of them since the establishment of the WTO 
in 1995. Over 180 are currently in force, with many more expected to be operational soon. Of the PTAs in force, 84 per cent are free trade agreements (FTAs), with customs unions (CUs) and partial-scope agreements making up the rest. Bilateral (country-to-country) agreements account for over 75 per cent of PTAs in force and almost 90 per cent of those under negotiation. The pace of PTA activity has increased since 1999/2000, and even more so since the launch of the Doha Round (WTO, 2006; Crawford and Fiorentino, 2005).

Eastern Europe, Africa and Latin America have long been involved in PTA activity. East Asia, which previously relied on non-discriminatory unilateral and multilateral liberalization, is now playing PTA catch-up, as is south Asia. All the major regional powers - China, India and Japan - are involved in Asian PTAs, as are the USA, EU, Korea, Australia, New Zealand, Hong Kong, other south-Asian countries and the ASEAN countries.

Why this rush? Proponents argue that small clubs of like-minded members can take liberalization and rules faster, wider and deeper than in the WTO, and act as 'building blocks' to further multilateral liberalization and rule-making. Sceptics say they are 'stumbling blocks', diverting attention from the WTO, creating 'spaghetti bowls' of discriminatory trade restrictions, and generally favouring powerful players at the expense of the weak (World Bank, 2004: ch. 6).

The reality is mixed. Unilateral and multilateral liberalization blunts the damaging effects of PTAs. There is little prospect of the world economy retreating to the warring trade blocs of the 1930s. Strong, 'WTO-plus' PTAs, that is with comprehensive sectoral coverage, more ambitious market-access and rules commitments than in the WTO, and simple, harmonized rules of origin, can also make sense. But these are rare. The EU, NAFTA and Australia-New Zealand CER are relatively strong PTAs. The record in developing-country regions, however, is not encouraging. South-South PTAs and most North-South PTAs tend to be driven by vague, muddled and trivial foreign-policy objectives with little relevance to commercial realities. Latin America and Africa have a messy patchwork of weak FTAs that do not liberalize much trade or improve upon WTO rules, but do create complications, especially through trade-restricting rules of origin, and divert attention both from the WTO and from unilateral reforms. This is also the emerging picture of FTAs in east and south Asia (Sally, 2006c).

The heart of the matter is that cross-border commerce in the developing world is throttled by the protectionist barriers that developing countries erect against their equally poor or even poorer neighbours. Will new PTAs make a big dent in these barriers and thereby spur regional and global economic integration? That looks doubtful. 


\section{The Role of Donors ${ }^{6}$}

Foreign aid, with conditions attached by the IMF, World Bank and other donors, has clearly played a big part in driving Washington Consensustype reforms in many developing countries. This has gone way beyond developing countries' (relatively weak) liberalizing commitments in the WTO and FTAs. Arguably, unilateral liberalization has not been truly 'unilateral' when it has depended on donor policy preferences and aid with strings attached. The record of IMF stabilization packages and World Bank structural adjustment packages has been mixed at best, and certainly disappointing compared with optimistic expectations in the 1980s (World Bank, 1998a; World Bank, 1998b). Often donor-driven reforms have proceeded in stops and starts, with reversals en route. Projected growth and poverty-alleviation effects have not materialized. The politics of aid is even more dubious than its economics. 'Conditionality' is empty rhetoric when self-serving interests at both ends of the pipeline ensure that aid continues to flow, even when promised reforms are not delivered. And the perception that Western donors are imposing reforms on otherwise reluctant countries is hardly sustainable: local 'ownership' is lacking (to borrow aid jargon), and it invites a backlash and reform-reversal at home (Bauer, 2000b).

The bottom line is that countries that have seen strong, sustained, unilateral liberalizing reforms are those whose governments have driven reforms ('from below', as it were) rather than having them imposed by donors ('from above'). Aid at its best has smoothed short-term adjustments; and donor conditionality has provided a 'good housekeeping seal of approval' - an international signal of reform credibility - more than anything else. In these countries (most in east Asia and eastern Europe, and a few in Latin America), aid has not been central to reform success. Where there has been more reliance on aid and donor conditionality, reforms have a far worse record. This applies to Africa in particular.

Seen in this light, the new conventional wisdom on aid is wrong-headed and dangerous. The UN Millennium Project and the Africa Commission Report both propose to double or even triple aid between 2005 and 2015, particularly with Africa in mind. The UN idea - or rather, Jeffrey Sachs's idea - is a new version of the old principle of aid: poor countries lack resources to invest, and donors have to fill this 'financing gap' with a 'big push' of investment if growth is ever to occur (UN, 2005; Sachs, 2005; Easterly, 1999). A sudden and massive increase of aid threatens to repeat past mistakes and provide extra incentives to delay and derail, not promote, market-based reforms. Available evidence shows that aid does not improve the productivity of investment; it diverts funds to stimulate government consumption and current spending; it has a negative impact 
on domestic savings; and, by expanding the role of already dysfunctional governments, it breeds waste and corruption. In short, this approach is misguided top-down intervention (Easterly, 2006).

A softer version of aid optimism, associated with the World Bank, assumes that countries are poor because of bad policy choices and weak institutions, and that aid can lock in already-accomplished reforms and facilitate additional reforms (World Bank, 1998a). This view is politically naive, though a convenient fiction for elites who profit from the aid business. The main objection is that aid has not and probably will not be a good midwife to market-based reforms. On the contrary, aid is given more often than not to support failed policies; and there is a high incidence of repeat lending to governments without a good track record of marketbased reforms.

A particular version of the aid-to-reform idea is the 'aid-for-trade' scheme that is now discussed in the Doha round. No one has yet defined its modus operandi. Is it a structural adjustment programme, an unemployment insurance programme, a budget support programme, an industrial promotion programme, or something else? Whatever the purpose, the history of aid warns us of the perils of such a scheme. Moreover, the idea that countries should be protected from the market-based structural adjustment that trade liberalization entails is in direct conflict with the reality of development.

\section{WHERE ARE WE GOING?}

The naysayers, from the hard and soft left, and the conservative right, hold that liberalization has not delivered the goods. They argue for various forms of government intervention, at national and international levels, to tame 'market fundamentalism' and 'neoliberal globalization'. Interventionist ideas on trade (and aid) are not new; they hark back to pre-Adam Smith, 'pre-analytic' mercantilism (as Schumpeter called it). What they have in common is an age-old distrust of markets and faith in government intervention - what David Henderson calls 'New Millennium Collectivism'. ${ }^{7}$ Such collectivist thinking is on the rise again. But it is still wrong and dangerous. It glosses over the damage done by interventionist policies in the past, and misreads the recent and historical evidence. The latter shows that external liberalization, as part of broad market-based reforms, has worked: countries that have become more open to the world economy have grown faster and become richer than those that have opened up less or remained closed.

There is much unfinished business. Barriers to trade, and the cross-border 
movement of capital and people, remain high, and more so in developing countries than in developed countries. But a combination of material circumstances and changes in the climate of ideas makes market-based reforms more difficult now than was the case a decade ago. Reform complacency has resulted from a post-crisis environment of buoyant growth and normal interest-group politics. There is dissatisfaction with previous reforms in parts of the developing world.

Moreover, the politics of 'second-generation' trade-policy reforms is proving much more difficult than that of 'first-generation' reforms. The former are all about complex domestic (though trade-related) regulation, such as services regulation, regulation of food-safety and technical standards, intellectual-property protection, public procurement, customs administration and competition rules. These reforms are technically and administratively difficult, and take time to implement. They demand a minimum of capacity across government, especially for implementation and enforcement. Above all, they are even more politically sensitive than border reforms, as they affect entrenched interests that are extremely difficult to dislodge.

The stakes, however, are too important for reform challenges to be avoided. While there is no imminent threat of global economic collapse, stalled reforms threaten to slow down globalization's advance, thereby depriving the world's least advantaged people of the life chances that globalization offers. That would reinforce strong pressures, from an alliance of old-style protectionist interests and new-style ideological forces, for overactive government to restrict economic freedom and the operation of the market economy. That is why new-old collectivist ideas need to be countered with full force. Reduction of what are still high barriers to trade, foreign investment and the cross-border movement of people holds the promise of higher growth, and significant poverty reduction and improvements in human welfare.

When thinking about the future reform agenda one should distinguish between 'first-division' and 'second-division' reformers. Second-division reformers, overwhelmingly in the low-income and least-developed bracket, have higher border barriers than first-division reformers, in addition to bigger domestic obstacles to trade and investment. They are less globalized. Their first priority should be to reduce border barriers and simple nonborder barriers (such as some red-tape procedures that give them low rankings in the World Bank's Doing Business Report). They have less capacity than first-division reformers for implementing more complex secondgeneration reforms. These could wait until the easier reforms are done. The real dilemma is that countries at the bottom of this pile, especially among the LDCs, are mired in political instability and civil strife, with failed and 
failing states that do not perform the most basic public functions. Such countries do not have the capacity to implement even simple reforms. Aiddriven solutions have failed, but what is the substitute? This book provides some hesitant answers based on the experiences of the countries studied, but the 'transferability' of these lessons is difficult to know.

First-division reformers are the 20-25 developing countries - the 'new globalizers' - that have already gone far with macroeconomic stabilization, and internal and external liberalization. They have plugged themselves into the globalization process. Their task is to go further with dismantling border barriers to trade and opening the door to FDI. But their bigger challenge is to make much more progress on trade-related domestic reforms - the 'structural' and 'institutional' reforms where progress to date has been too slow. This entails tackling the second-generation issues mentioned above. What is needed is a culture of permanent, incremental reforms, mainly of the second-generation variety, that build on the foundations of first-generation reforms, so that the economy adapts flexibly to changing global conditions. That is easier said than done. The great difficulty lies in doing serious reforms in conditions of normal interest-group politics, without an economic crisis to concentrate minds. But the alternative is creeping sclerosis in times of plenty, and excessive reliance on a crisis for the next reform wave (Olson, 1982; OECD, 2007). That cannot be good for long-term political, social and economic health.

Fundamentally, required reforms boil down to restructuring the state, away from the large overactive state that intervenes badly across the range of economic activity, and towards the limited state that performs a smaller number of core functions well. The latter should focus on providing and enforcing a framework of rules for market-based competition. To use Michael Oakeshott's distinction, the state should be an 'umpire' of a 'civic association', not an 'estate manager' of an 'enterprise association'.

Thus it falls to friends of the market economy to make a strong case for further reforms, including external liberalization, and practically go about assembling reform coalitions. In the next seven chapters there is ample evidence to show how this might be both achieved and sustained.

\section{NOTES}

1. On the record of trade and FDI liberalization as part of larger packages of marketbased reforms in developing countries and countries in transition, see Williamson, 1994; Kuczynski and Williamson, 2004; Lal and Myint, 1996; Dean, 1995; Drabek and Laird, 1998; Henderson, 1998; Michalopoulos, 2001; Bates and Krueger, 1993; Desai, 1997. On trade policy trends in Asia, see Sally, 2007, 2006b; Sally and Sen, 2005.

2. Ricardo-Viner and Hecksher-Ohlin models of comparative advantage are used to 
explain interest-group activity pro and contra free trade in different countries with different factor endowments. See Rogowski (1990).

3. On 'ideational' approaches, see Goldstein (1994).

4. There is the theoretical possibility of (usually large) countries being able to exercise longrun market power in international demand for certain goods. This enables them to shift the terms of trade in their favour by means of an 'optimal tariff'. The corollary is that these countries should only lower tariffs if others reciprocate, in order to avoid worsening terms of trade. In reality, very few countries have such long-run market power. And retaliatory tariffs by other countries could nullify terms-of-trade gains. Thus - not for the first time - a neat theory turns out to have limited practical relevance. See Irwin, 1996: $106-115$.

5. The following argument draws on Sally, 2006a.

6. This section draws on Erixon and Sally, 2006.

7. On the provenance and progress of these ideas, see Henderson (2001).

\section{REFERENCES}

Balcerowicz, Leczek (1995), Socialism, Capitalism, Transformation, Budapest: Central European University Press.

Bates, Robert and Anne Krueger (eds) (1993), Political and Economic Interactions in Economic Policy Reform: Evidence from Eight Countries, Cambridge, MA: Blackwell.

Bauer, P.T. (2000a), From Subsistence to Exchange and Other Essays, Princeton, NJ: Princeton University Press.

Bauer, P.T. (2000b), 'Foreign aid: abiding issues', in P.T. Bauer, From Subsistence to Exchange and Other Essays, Princeton, NJ: Princeton University Press.

Bhagwati, Jagdish and T.N. Srinivasan (1999), 'Outward-orientation and development: are revisionists right?', Yale University Economic Growth Center Discussion Paper no. 806, 17 September.

Chang, Ha-Joon (2002), Kicking Away the Ladder: Development Strategy in Historical Perspective, London: Anthem Press.

Crawford, Jo-Ann and Robert Fiorentino (2005), 'The changing landscape of regional trade agreements', WTO Discussion Paper No. 8, available at www. wto.org.

Dean, Judith (1995), 'The trade-policy revolution in developing countries', in S. Arndt and C. Milner (eds), The World Economy, Global Trade Policy, Oxford: Blackwell.

Desai, Padma (ed.) (1997), Going Global: Transition from Plan to Market in the World Economy, Cambridge, MA: MIT Press.

Drabek, Zdenek and Sam Laird (1998), 'The new liberalism: trade-policy developments in emerging markets', Journal of World Trade, 32(5), 241-69.

Easterly, William (1999), 'The Ghost of the Financing Gap: Testing the Growth Model Used in the International Financial Institutions', Journal of Development Economics, 60(2).

Easterly, William (2006), The White Man's Burden: Why the West's Efforts to Aid the Rest Have Done So Much Ill and So Little Good, New York: Penguin.

Erixon, Fredrik and Razeen Sally (2006), 'Trade and aid: countering New Millennium Collectivism', Australian Economic Review, 39(1), 69-77. 
Goldstein, Judith (1994), Ideas, Interests and American Trade Policy, Ithaca: Cornell University Press.

Grunberg, Isabel, I. Kaul and M. Stern (eds) (1999), Global Public Goods: International Co-operation in the 21st Century, New York and Oxford: Oxford University Press.

Haggard, Stephen and John Williamson (1993), 'The political conditions for economic reform', 1994, in Williamson, 1994, op cit., pp. 527-96.

Henderson, David (1992), 'International economic integration: progress, prospects and implications', International Affairs, 64(4).

Henderson, David (1998), The Changing Fortunes of Economic Liberalism: Yesterday, Today and Tomorrow, London: Institute of Economic Affairs.

Henderson, David (2001), Anti-Liberalism 2000: The Rise of New Millennium Collectivism, London: Institute of Economic Affairs.

Henderson, David (2004), 'Globalisation, economic progress and New Millennium Collectivism', World Economics, 5(3), July-September, 43-73.

Ingco, M.D. and J.D. Nash (eds) (2004), Agriculture and the WTO: Creating a Trading System for Development, Washington, DC: World Bank.

Irwin, Douglas (1996), Against the Tide: An Intellectual History of Free Trade, Princeton, NJ: Princeton University Press.

Krueger, Anne (1974), 'The political economy of the rent-seeking society', American Economic Review, 64, 291-303.

Kuczynshi, P.P. and T. Williamson (eds) (2004), After the Washington Consensus: Restarting Growth and Reform in Latin America, Washington, DC: Institute for International Economics.

Lal, Deepak and H. Myint (1996), The Political Economy of Poverty, Equity and Growth: A Comparative Study, Oxford: Clarendon Press.

Little, I.M.D. (1999), 'Trade and industrialisation revisited', in I.M.D. Little (ed.), Collection and Recollections, Oxford: Clarendon Press.

Maddison, Angus (2003), The World Economy: Historical Statistics, Paris: OECD.

Messerlin, Patrick (2005), Europe After the 'No' Votes: Mapping a New Economic Path, London: Institute of Economic Affairs.

Michalopoulos, Constantine (2001), Developing Countries and the WTO, London: Palgrave.

Olson, Mancur (1971), The Logic of Collective Action: Public Goods and the Theory of Groups, Cambridge, MA: Harvard University Press.

Olson, Mancur (1982), The Rise and Decline of Nations: Economic Growth, Stagflation and Social Rigidities, New Haven: Yale University Press.

Organisation of Economic Cooperation and Development (OPED) (2007), Economic Policy Reforms: Going for Growth, Paris: OECD.

Oxfam (2002), Rigged Rules and Double Standards: Trade, Globalisation and the Fight Against Poverty, Oxford: Oxfam International, www.maketradefair.com.

Rodrik, Dani (1998), The New Global Economy and Developing Countries: Making Openness Work, Washington, DC: Overseas Development Council.

Rodrik, Dani (2001), 'Trading in illusions', Foreign Policy, March/April, www. foreignpolicy.com/issue_marapr_2001/rodrick.html.

Rogowski, Ronald (1990), Commerce and Coalitions: How Trade Affects Domestic Political Alignments, Princeton, NJ: Princeton University Press.

Sachs, Jeffrey (2005), The End of Poverty: How We Can Make it Happen in our Lifetime, London: Penguin. 
Sachs, Jeffrey and Andrew Warner (1995), 'Economic reform and the process of global integration', Brookings Papers on Economic Activity, 1.

Sally, Razeen (1998), Classical Liberalism and International Economic Order: Studies in Theory and Intellectual History, London: Routledge.

Sally, Razeen (2006a), 'Trade policy 2006: a tour d'horizon', World Economics, 7(1), January-March, 49-71.

Sally, Razeen (2006b), 'Chinese trade policies in wider Asian perspective', in Yang Yao and Linda Yueh (eds), Globalisation and Economic Growth in China, London: World Scientific Publishing, pp. 181-233.

Sally, Razeen (2006c), 'FTAs and the prospects for regional integration in Asia', ECIPE Working Paper 1, www.ecipe.org/publications/2006/WPno1_06_Sally. pdf.

Sally, Razeen (2007), 'Trade policy in Asia', ECIPE Policy Brief, 1, www.ecipe.org/ pdf/Policybrief_0107.pdf.

Sally, Razeen and Rahul Sen (2005), 'Whither trade policies in southeast Asia? The wider Asian and global context', ASEAN Economic Bulletin, 22(1), April, 92-115, Special Issue 'Revisiting trade policies in southeast Asia', Razeen Sally and Rahul Sen (eds).

Stiglitz, Joseph (2002), Globalisation and its Discontents, London: Allen Lane.

UN Millennium Project (2005), Investing in Development: a Practical Plan to Achieve the Millennium Development Goals, New York: Earthscan.

Wade, Robert Hunter (1990), Governing the Market, Princeton, NJ: Princeton University Press.

Williamson, John(ed.) (1994), The Political Economy of Policy Reform, Washington, DC: Institute for International Economics.

Winters, L. Alan (2004), 'Trade liberalisation and economic performance: an overview', Economic Journal, February.

Winters, L. Alan et al. (2004), 'Trade liberalisation and poverty', Journal of Economic Literature, March.

Wolf, Martin (2004), Why Globalisation Works: The Case for the Global Market Economy, New Haven: Yale University Press.

World Bank (1993), The East Asian Miracle, Washington DC: World Bank.

World Bank (1997), World Development Report 1997: The State in Economic Development, Washington, DC: World Bank.

World Bank (1998a), Assessing Aid: What Works, What Doesn't, and Why, New York: Oxford University Press.

World Bank (1998b), 1998 Annual Review of Development Effectiveness, Washington, DC: World Bank Operations Evaluation Department.

World Bank (2002a), Globalisation, Growth and Poverty: Building an Inclusive World Economy, Washington, DC: World Bank.

World Bank (2002b), Global Economic Prospects and the Developing Countries: Making Trade Work for the World's Poor, Washington, DC: World Bank.

World Bank (2004), Global Economic Prospects 2005: Trade, Regionalism and Development, Washington, DC: World Bank.

World Bank (2006), Doing Business in 2007, Washington, DC: World Bank.

World Trade Organisation (2006), 'Regional trade agreements: facts and figures', www.wto.org/english/tratop_e/region_e/regfac_e.htm. 